\title{
Quality of life in children and young people with tetraplegic cerebral palsy
}

\author{
Jakość życia dzieci i młodzieży z postacią czterokończynową mózgowego \\ porażenia dziecięcego
}

\author{
Agata Michalska¹, Małgorzata Markowska², Zbigniew Śliwiński,3, Justyna A. Pogorzelska4,5 \\ ${ }^{1}$ Department of Department of Neurology, Neurologic Rehabilitation and Kinezytherapy, Institute of Physiotherapy, Faculty of Health \\ Sciences, Jan Kochanowski University, Kielce, Poland \\ Head of the Department: Prof. JKU Zbigniew Śliwiński MD, PhD \\ 2Department of Pathobiomechanics, Institute of Physiotherapy, Faculty of Health Sciences, Jan Kochanowski University, Kielce, Poland \\ Head of the Department: Prof. Andrzej Rydzewski \\ ${ }^{3}$ Multispecialist Independent Public Health Care Centre, Stationary Rehabilitation Centre, Physiotherapy Centre, Zgorzelec, Poland \\ Head of the Centre: Prof. JKU Zbigniew Śliwiński MD, PhD \\ ${ }^{4}$ Department of Physical Medicine, Institute of Physiotherapy, Faculty of Medicine and Health Science, Jan Kochanowski University, \\ Kielce, Poland \\ Head of the Department: Prof. Włodzisław Kuliński MD, PhD \\ ${ }^{5}$ Department of Physiotherapy, Świętokrzyskie Center of Pediatrics, Kielce, Poland \\ Head of the Department: Wojciech Kiebzak PhD
}

Key words: quality of life, intellectual disability, tetraplegic, cerebral palsy.

Słowa kluczowe: jakość życia, niepełnosprawność intelektualna, tetraplegia, mózgowe porażenie dziecięce.

\begin{abstract}
Introduction: Health-related quality of life (HRQOL) is an important outcome of health interventions for children and youths with cerebral palsy $(\mathrm{CP})$.

Aim of the research: To describe HRQOL of children and young people with tetraplegic cerebral palsy from the parents' perspectives, and explore the impact of four factors (severity of CP, intellectual disability, age, and gender) on HRQOL.

Material and methods: This is a descriptive study, conducted in educational centres in central and southern Poland. The study encompassed a group of 149 children and youths with tetraplegic cerebral palsy (TCP). The HRQOL study described in this paper was carried out using the PedsQL 4.0 Generic Core and PedsQL 3.0 Cerebral Palsy Module.

Results: The lowest subscale score in generic core scales was physical functioning (mean \pm SD: 11.1 \pm 8.5 ), the highest being emotional functioning $(47.1 \pm 22.2)$. The lowest subscale score in CP module was daily activities $(3.2 \pm 8.5)$, the highest being pain and hurt $(57.1 \pm 29.3)$. PedsQL scores were related to MASC level, GMFCS level, and degree of intellectual disability, but not gender. Age correlated only with the assessment of pain and hurt (Pearson $r=-0.190 ; p=0.020$ ). This study showed significant deficits in HRQOL for children with TCP, especially as regards their physical HRQOL.

Conclusions: More studies aimed at searching factors related to psychosocial HRQOL are needed. In relation with the increasing life expectancy of persons with TCP, parents and health professionals should pay more attention to appropriate assessment of pain.
\end{abstract}

\section{Streszczenie}

Wprowadzenie: Jakość życia uwarunkowana stanem zdrowia (HRQOL) jest ważnym skutkiem interwencji zdrowotnych u dzieci i młodzieży z mózgowym porażeniem dziecięcym.

Cel pracy: Przedstawienie charakterystyki HRQOL dzieci i młodzieży z postacią tetraplegiczną mózgowego porażenia dziecięcego sporządzonej na podstawie oceny rodziców, a także analiza wpływu na nią czterech czynników (stopnia ciężkości porażenia mózgowego, niepełnosprawności intelektualnej, wieku oraz płci).

Materiał i metody: Jest to badanie opisowe przeprowadzone w placówkach edukacyjnych zlokalizowanych w środkowej i południowej Polsce. W badaniu udział wzięło 149 osób z postacią tetraplegiczną mózgowego porażenia dziecięcego. Do oceny HRQOL zastosowano PedsQL 4.0 Generic Core i PedsQL 3.0 Cerebral Palsy Module.

Wyniki: Najniższą ocenę dla Generic Core Scales uzyskano w podskali funkcjonowanie fizyczne (średnia \pm odchylenie standardowe: $11,1 \pm 8,5)$, a najwyższą dla funkcjonowania emocjonalnego $(47,1 \pm 22,2)$. Najniższą ocenę w CP Module uzyskano 
dla czynności codziennych $(3,2 \pm 8,5)$, natomiast najwyższą dla podskali bólu $(57,1 \pm 29,3)$. Wynik PedsQL korelował z poziomem systemów MACS i GMFCS, stopniem niepełnosprawności intelektualnej, ale nie z płcią badanych. Wiek był powiązany jedynie z oceną bólu $(r=-0,190 ; p=0,020)$. W badaniu stwierdzono istotnie niższą jakość życia uwarunkowaną stanem zdrowia osób z postacią tetraplegiczną mózgowego porażenia dziecięcego, zwłaszcza w obszarze funkcjonowania fizycznego.

Wnioski: Obszar psychospołeczny HRQOL wymaga badań ukierunkowanych na poszukiwanie czynników modulujących. Ze względu na wydłużający się czas życia osób z mózgowym porażeniem dziecięcym zarówno rodzice, jak i pracownicy opieki zdrowotnej powinni zwrócić uwagę na właściwą ocenę występującego u nich bólu.

\section{Introduction}

Cerebral palsy $(\mathrm{CP})$ is the most common motor disability of childhood. It is an individually specific complex, with unstable clinical picture and functional status, in which (next to movement disorders) the following coexisting disorders may occur: disturbances of sensation, cognition, communication, perception and/or behaviour, and/or a seizure disorder [1]. Their presence and severity depends on the localisation and extent of brain damage. Based on test data, one may say that intellectual disability (IQ < 70) occurs in $31-65 \%$ patients with CP, whereas epilepsy occurs in $20-46 \%$, vision impairment in $2-19 \%$, hearing impairment in $2-15 \%$, and severely impaired/no speech and feeding problems in 50\% [2-5]. Their presence has a fundamental impact on the patients' quality of life, life expectancy, functional status, ability to perform independent activities, and participation.

Most CP cases (approx. 90\%) are of spastic form, such as monoplegia, hemiplegia, diplegia, and tetraplegia [4, 6]. Tetraplegic cerebral palsy (TCP) is the most severe type of spastic CP. Its occurrence is assessed at $5.5-35 \%$ of cases [7-10]. It is a form of CP in which pareses concern all four limbs. Paresis of the upper limbs is greater than or the same degree as in the lower limbs [11]. The causes of tetraplegia may be of pre-, peri-, and postnatal character. They include: perinatal asphyxia, periventricular leukomalacia (PVL), malformations, infection, and genetic abnormalities [3, 12]. In this clinical form brain injuries are often broad and diffuse, on both cortical and subcortical structures. This results in more frequent, than in other forms, occurrence of epilepsy, intellectual disability, difficulties in communication, difficulties in food intake, and sensory deficits [3, 8, 9, 11-13]. More extensive are also secondary osteoskeletal changes, respiratory disorders, and gastrointestinal disorders, including eating disorders.

Complex consequences of the abovementioned deficits, concerning various spheres of functioning of persons with TCP, may have a negative effect on their quality of life. Quality of life (QoL) is an individual's perception of their position in life in the context of the culture and value systems in which they live, and in relation to their goals, expectations, standards, and concerns [14]. Health-related quality of life (HRQOL) is a narrower term. These are feelings of an individual on the impact of their health status on various aspects of their own lives. Quality of life and HRQOL are pri- ority outcomes for health and rehabilitation services [15]. Despite a great deal of interest in HRQOL in children, little information is available regarding the most severe type of $\mathrm{CP}$.

\section{Aim of the research}

The aim of this study was the assessment of HRQOL in children and youths with spastic tetraplegia and intellectual disability.

\section{Material and methods}

The study encompassed a group of 149 children and adolescents with TCP. The tool used in the study was the PedsQL 4.0 Generic Core and PedsQL 3.0 Cerebral Palsy Module. In the study, out of necessity, the possibility of a self-completion questionnaire was abandoned, instead opting for reporting by parents (parent proxy-report). The reasons were communication problems and intellectual disability $(\mathrm{IQ}<34)$ occurring in all patients. Parent proxy-report includes ages 2-4 years (toddler), 5-7 years (young child), 8-12 years (child), and 13-18 years (adolescent), and assesses the parent's perception of their child's HRQOL. Both types of evaluation are considered to be important sources of information about the child's quality of life. Parent reports should be treated rather as complementary information [16-18], because the parent's psychological well-being may indirectly affect the assessment of the quality of life of children [19-21]. In the study, in all cases the questionnaires were filled out by the mother or in the case of bereavement ( 4 cases) by the grandmother of respondents who were affected the most by child care (later referred to as caregivers).

The both scales are reliable and valid measures of HRQOL [22-27]. The 23-item PedsQL 4.0 Generic Core Scales encompass: physical functioning (eight items), emotional functioning (five items), social functioning (five items), and school functioning (five items). To create the psychosocial health summary score, the mean is computed as the sum of the items divided by the number of items answered in the emotional, social, and school functioning scales [24]. The 35-item PedsQL 3.0 CP Module encompasses seven scales: daily activities (nine items), school activities (four items), movement and balance (five items), pain and hurt (four items), fatigue (four items), eating activities (five items), and speech and communication (four items). For the parent report for toddlers' form (aged 
2-4 years) there are no school activities or speech and communication scales, and the daily activities and eating activities scales are modified to include fewer items (not all items were applicable for toddlers) [27]. The instructions ask how much of a problem each item has been for the past month. A five-point response scale is used $(0$ - never a problem; 1 - almost never a problem; 2 - sometimes a problem; 3 - often a problem; 4 - almost always a problem). The items are reverse-scored and linearly transformed to a $0-100$ scale $(0=100,1=$ $75,2=50,3=25,4=0$ ), so that higher scores indicate higher HRQOL [24].

The study was designed in such a way that the age-appropriate questionnaires were handed over to caregivers via the staff of educational institutions the respondents attended. Institutions included in the study were located in central and southern Poland.

Table 1. Characteristics of the study population

\begin{tabular}{|c|c|}
\hline Characteristics & $N(\%)$ \\
\hline \multicolumn{2}{|l|}{ Gender: } \\
\hline Male & $85(57)$ \\
\hline Female & $64(43)$ \\
\hline \multicolumn{2}{|l|}{ Age [years]: } \\
\hline $2-4$ & $8(5.4)$ \\
\hline $5-7$ & $14(9.4)$ \\
\hline $8-13$ & $53(35.5)$ \\
\hline$>13$ & $74(49.7)$ \\
\hline \multicolumn{2}{|l|}{ Degree of intellectual disability: } \\
\hline $\mathrm{IQ}<20$ (profound) & $88(61)$ \\
\hline IQ 20-34 (severe) & $57(39)$ \\
\hline \multicolumn{2}{|l|}{ GMFCS (level): } \\
\hline II & $2(1.3)$ \\
\hline III & $5(3.4)$ \\
\hline IV & $54(36.2)$ \\
\hline V & $88(59.1)$ \\
\hline \multicolumn{2}{|l|}{ MACS (level): } \\
\hline II & $3(2.0)$ \\
\hline III & $19(12.8)$ \\
\hline IV & $55(36.9)$ \\
\hline V & $72(48.3)$ \\
\hline \multicolumn{2}{|c|}{ Accompanied diseases and dysfunctions: } \\
\hline Epilepsy & $92(61.7)$ \\
\hline Visual impairments & $60(40.3)$ \\
\hline Hearing impairments & $12(8.1)$ \\
\hline No diseases or dysfunctions & $36(24.3)$ \\
\hline
\end{tabular}

After filling in the questionnaire it was returned to the facility, where it was checked for the correctness of filling in and topped with a functional classification using the Gross Motor Function Classification System (GMFCS) and Manual Ability Classification System (MACS) by a physiotherapist. The GMFCS and MACS were used to determine the severity of CP (Levels I through $\mathrm{V}$, with $\mathrm{V}$ as the most severe impairment). The inclusion criterion was diagnosis of TCP confirmed by medical history.

The study was approved by the Ethics Committee at the Health Sciences Faculty at the Jan Kochanowski University in Kielce.

\section{Statistical analysis}

Means, standard deviation, median, min, and max were calculated for continuous data. For group comparisons of continuous variables, ANOVA was used. The Pearson correlation was used to examine the relationship between the age and the PedsQL scales. The Spearman rank correlation was used to examine the relationship between ranked variables and the PedsQL scales. A significance level of 0.05 was used throughout.

\section{Results}

The caregivers evaluating the quality of life were persons with secondary education $(46 \%)$ or primary and vocational education (39\%), rarely higher education (15\%). Most of them (78\%) gave up paid work to care for the child. The average age of the evaluators was $40 \pm 7.0$ years (min. 22, max. 57). Subjects with TCP were mostly teenagers (almost $50 \%$ of respondents over 13 years of age), often classified into levels IV (36.2\%) and V (59.1\%) of GMFCS and levels IV (36.9\%) and V (48.3\%) of MACS. They were characterised by the presence of intellectual disability of severe and profound degree $(61 \%$ IQ < 20). The most common coexisting disorder was epilepsy, occurring in $61.7 \%$ of patients. During the study all persons attended special educational institutions. Table 1 shows the general characteristics of the study group.

Table 2 presents results of the Generic Core Scales and CP Module. The lowest assessed subscale of Generic Core Scales was physical functioning (11.1 \pm 8.5 ), and the highest was emotional functioning (47.1 \pm 22.2 ). The PedsQL Module CP subscale analysis revealed lower scores of daily activities and school activities, speech, and eating activities.

No significant correlations between HRQOL scores and gender of the studied group were found (data not shown). Age correlated only with the assessment of pain (Pearson $r=-0.190, p=0.020$ ). Statistically significant difference in the pain subscale between groups 2-4 years old and groups of more than 8 years of age was noted (2-4 years: 
Table 2. PedsQL Generic Core Scales and Cerebral Palsy Module scores

\begin{tabular}{|c|c|c|c|c|c|c|}
\hline PedsQL scales & $N$ & Mean & SD & Min. & $\mathrm{Me}$ & Max. \\
\hline \multicolumn{7}{|l|}{ Generic Core Scales } \\
\hline Physical functioning & 149 & 11.1 & 8.5 & 0 & 12.5 & 37.5 \\
\hline Emotional functioning & 149 & 47.1 & 22.2 & 0 & 50 & 100 \\
\hline Social functioning & 149 & 36.7 & 26.1 & 0 & 35 & 100 \\
\hline School functioning & 149 & 34.7 & 21.7 & 0 & 35 & 100 \\
\hline Psychosocial functioning & 149 & 40.1 & 18.7 & 0 & 41.7 & 86.7 \\
\hline Overall score & 149 & 29.1 & 13.6 & 0 & 30.4 & 68.5 \\
\hline \multicolumn{7}{|l|}{ CP Module } \\
\hline Pain and hurt & 149 & 57.1 & 29.3 & 0 & 56.3 & 100 \\
\hline Fatigue & 149 & 43.7 & 21.2 & 0 & 43.8 & 100 \\
\hline Eating activities & 149 & 16.9 & 20.0 & 0 & 10 & 85.0 \\
\hline Speech & 141 & 18.2 & 27.7 & 0 & 0 & 100 \\
\hline Daily activities & 149 & 3.2 & 8.5 & 0 & 0 & 47.2 \\
\hline School activities & 141 & 5.6 & 13.3 & 0 & 0 & 75 \\
\hline Movement and balance & 149 & 26.5 & 26.3 & 0 & 20 & 100 \\
\hline
\end{tabular}

$81.25 \pm 25.44$ vs. $8-13$ years: $52.99 \pm 29.04, p=0.006$; 2-4 years: $81.25 \pm 25.44$ vs. $>13$ years: $54.81 \pm 27.19$, $p=0.008)$. The level of MACS correlated with all areas of the generic and specific scale. The level of GMFCS and degree of intellectual disability of the studied groups correlated with some areas of both scales (Table 3). Children in Level V of GMFCS and MACS, i.e. judged to be most severely affected, had the lowest HRQOL scores in all domains of the PedsQL Generic Core Scale and CP Module (Tables 4, 5). Subjects with TCP and severe mental retardation (IQ 34-20) scored higher in both PedsQL scales than respondents with profound mental retardation $(\mathrm{IQ}<20)$. These differences were statistically significant for all items, except for social functioning and movement and balance (data not shown).

\section{Discussion}

The HRQOL of children and adolescents with CP is a topic often discussed in the literature, although usually research focuses on milder forms of CP. The results confirm that the HRQOL of people with $\mathrm{CP}$ is lower than that of healthy children [28-37]. Only Dickinson et al. [38] reported no differences between the two groups. The quality of life of people with $\mathrm{CP}$ is comparable to patients treated for cancer and rheumatic diseases [39], patients with myelomeningocele [40], or with neuromuscular diseases [41]. The health-related quality of life in TCP patients is significantly lower compared with other types of $\mathrm{CP}$ $[27,28,42]$.
The Generic Core of the PedsQL 4.0 and CP Module scores presented in Table 2 demonstrated significantly lower health-related quality of life compared with two literature-based groups with TCP [27, 28]. Significant differences were found for physical functioning score $(11.1 \pm 8.5$ vs. $31.04 \pm 27.92$ and 33.78 $\pm 29.07)$, and similar results for psychosocial functioning score $(40.1 \pm 18.7$ vs. $51.72 \pm 15.56$ and 49.96 $\pm 15.63)$. As in other studies [27, 28, 43, 44] physical functioning score was lower than psychosocial health score. Varni et al. [28] claim that children with TCP have diminished physical (but not psychosocial) wellbeing when compared with those with other spasticity types. This raises the question of whether parents of children with TCP are not too optimistic about their emotional and social functioning, and whether they can assess it objectively. This applies particularly to such elements of the PedsQL questionnaire as the feeling of fear, sadness, anger, or establishing relationships with peers. Although most interventions aim to improve physical independence, a lot more could be done in the wider society to improve social inclusion and participation of children with CP [45].

The PedsQL CP Module showed that patients had the greatest difficulties with daily and school activities, and the least with pain and hurt, and fatigue, which is comparable with the results obtained by Varni et al. [27].

The PedsQL scores of patients with TCP were related to their GMFCS level, MACS level, and degree of intellectual disability, but not age and gender. Severe disability and the presence of numerous coexistent 
Table 3. Correlation between PedsQL scores and degree of intellectual disability, GMFCS level, and MACS level

\begin{tabular}{|c|c|c|c|c|c|c|c|}
\hline \multirow[t]{2}{*}{ PedsQL scales } & \multirow[t]{2}{*}{$N$} & \multicolumn{2}{|c|}{$\begin{array}{c}\text { Degree of intellectual } \\
\text { disability }\end{array}$} & \multicolumn{2}{|c|}{ GMFCS level } & \multicolumn{2}{|c|}{ MACS level } \\
\hline & & $r$ & $p$ & $r$ & $p$ & $r$ & $p$ \\
\hline \multicolumn{8}{|l|}{ Generic Core Scales } \\
\hline Physical functioning & 149 & 0.239 & 0.004 & -0.347 & $<0.001$ & -0.474 & $<0.001$ \\
\hline Emotional functioning & 149 & 0.204 & 0.014 & -0.316 & $<0.001$ & -0.402 & $<0.001$ \\
\hline Social functioning & 149 & 0.137 & 0.102 & -0.024 & 0.772 & -0.227 & 0.005 \\
\hline School functioning & 149 & 0.252 & 0.003 & -0.116 & 0.183 & -0.271 & 0.002 \\
\hline Psychosocial functioning & 149 & 0.241 & 0.003 & -0.159 & 0.053 & -0.350 & $<0.001$ \\
\hline Overall score & 149 & 0.304 & $<0.001$ & -0.218 & 0.008 & -0.406 & $<0.001$ \\
\hline \multicolumn{8}{|l|}{ CP Module } \\
\hline Pain and hurt & 149 & 0.202 & 0.015 & -0.290 & $<0.001$ & -0.378 & $<0.001$ \\
\hline Fatigue & 149 & 0.193 & 0.020 & -0.193 & 0.018 & -0.376 & $<0.001$ \\
\hline Eating activities & 149 & 0.362 & $<0.001$ & -0.427 & $<0.001$ & -0.477 & $<0.001$ \\
\hline Speech & 141 & 0.443 & $<0.001$ & -0.161 & 0.057 & -0.386 & $<0.001$ \\
\hline Daily activities & 149 & 0.265 & $<0.001$ & -0.200 & 0.014 & -0.287 & $<0.001$ \\
\hline School activities & 141 & 0.548 & $<0.001$ & -0.282 & $<0.001$ & -0.431 & $<0.001$ \\
\hline Movement and balance & 149 & 0.154 & 0.064 & -0.543 & $<0.001$ & -0.496 & $<0.001$ \\
\hline
\end{tabular}

$r$-Spearman rank correlation coefficient.

Tabel 4. Generic Core Scales and CP Module mean subscale scores stratified by GMFCS

\begin{tabular}{|c|c|c|c|c|c|c|c|c|c|}
\hline \multirow[t]{2}{*}{ PedsQL scales } & \multicolumn{2}{|c|}{ GMFCS II } & \multicolumn{2}{|c|}{ GMFCS III } & \multicolumn{2}{|c|}{ GMFCS IV } & \multicolumn{2}{|c|}{ GMFCS V } & \multirow{2}{*}{$\begin{array}{l}\text { ANOVA } \\
P \text {-value }\end{array}$} \\
\hline & Mean & SD & Mean & SD & Mean & SD & Mean & SD & \\
\hline \multicolumn{10}{|l|}{ Generic Core Scales } \\
\hline Physical functioning & 20.31 & 6.63 & 16.87 & 11.61 & 14.35 & 9.45 & 8.63 & 6.77 & $<0.001^{1}$ \\
\hline Emotional functioning & 60.00 & 0.00 & 66.00 & 13.87 & 53.43 & 20.11 & 41.78 & 22.53 & $0.003^{2}$ \\
\hline Social functioning & 25.00 & 35.36 & 38.00 & 16.05 & 37.71 & 26.27 & 36.31 & 26.65 & 0.918 \\
\hline School functioning & 40.00 & 14.14 & 37.50 & 11.90 & 36.70 & 21.26 & 33.05 & 22.66 & 0.792 \\
\hline $\begin{array}{l}\text { Psychosocial } \\
\text { functioning }\end{array}$ & 41.67 & 16.50 & 48.40 & 8.34 & 43.41 & 17.88 & 37.64 & 19.41 & 0.240 \\
\hline Overall score & 34.24 & 13.06 & 35.64 & 6.83 & 32.21 & 13.37 & 26.79 & 13.71 & 0.077 \\
\hline \multicolumn{10}{|l|}{ CP Module } \\
\hline Pain and hurt & 100.00 & 0.00 & 75.00 & 23.39 & 64.39 & 29.16 & 50.69 & 27.96 & $0.003^{3}$ \\
\hline Fatigue & 84.38 & 4.42 & 53.75 & 14.39 & 47.30 & 20.65 & 40.02 & 20.66 & $0.004^{4}$ \\
\hline Eating activities & 30.00 & 42.43 & 49.50 & 31.74 & 25.60 & 22.65 & 9.49 & 11.45 & $<0.001^{5}$ \\
\hline Speech & 0.00 & 0.00 & 50.00 & 48.14 & 22.62 & 29.43 & 14.62 & 24.79 & $0.030^{6}$ \\
\hline Daily activities & 0.00 & 0.00 & 16.11 & 22.60 & 5.14 & 10.41 & 1.33 & 4.10 & $0.000^{7}$ \\
\hline School activities & 0.00 & 0.00 & 26.56 & 33.22 & 8.55 & 15.50 & 3.13 & 9.09 & $0.001^{8}$ \\
\hline $\begin{array}{l}\text { Movement } \\
\text { and balance }\end{array}$ & 92.50 & 10.61 & 66.00 & 18.51 & 39.63 & 26.60 & 14.77 & 17.10 & $<0.001^{9}$ \\
\hline
\end{tabular}

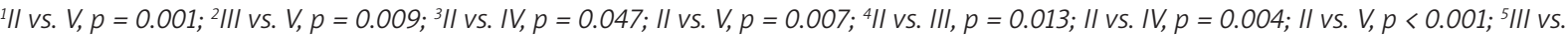

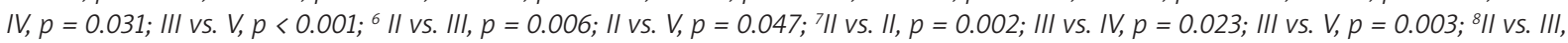
$p=0.001$; III vs. IV, $p=0.02$; III vs. V, $p=0.004 ;{ }^{9} I I$ vs. III, $p=0.037$; II vs. IV, $p<0.001$; IV vs. V, $p<0.001 ;$ III vs. IV, $p=0.038 ;$ III vs. V, $p<0.001$. 
Table 5. Generic Core Scales and CP Module mean subscale scores stratified by MACS

\begin{tabular}{|c|c|c|c|c|c|c|c|c|c|}
\hline \multirow[t]{2}{*}{ PedsQL scales } & \multicolumn{2}{|c|}{ MACS II } & \multicolumn{2}{|c|}{ MACS III } & \multicolumn{2}{|c|}{ MACS IV } & \multicolumn{2}{|c|}{ MACS V } & \multirow{2}{*}{$\begin{array}{l}\text { ANOVA } \\
P \text {-value }\end{array}$} \\
\hline & Mean & SD & Mean & SD & Mean & SD & Mean & SD & \\
\hline \multicolumn{10}{|l|}{ Generic Core Scales } \\
\hline Physical functioning & 28.12 & 13.62 & 15.95 & 9.65 & 13.81 & 7.99 & 7.12 & 5.80 & $<0.001^{1}$ \\
\hline Emotional functioning & 68.33 & 12.58 & 59.34 & 16.66 & 53.36 & 17.13 & 38.11 & 23.68 & $<0.001^{2}$ \\
\hline Social functioning & 45.00 & 13.23 & 43.93 & 24.56 & 41.20 & 26.25 & 31.05 & 25.99 & 0.079 \\
\hline School functioning & 41.67 & 15.28 & 37.76 & 17.58 & 41.60 & 20.97 & 28.32 & 22.14 & $0.011^{3}$ \\
\hline Psychosocial functioning & 54.31 & 5.67 & 47.10 & 13.03 & 45.99 & 15.79 & 33.25 & 19.98 & $<0.001^{4}$ \\
\hline Overall score & 44.68 & 3.77 & 35.70 & 9.77 & 33.50 & 11.64 & 23.45 & 13.78 & $<0.001^{5}$ \\
\hline \multicolumn{10}{|l|}{ CP Module } \\
\hline Pain and hurt & 64.58 & 13.01 & 75.99 & 20.76 & 64.28 & 26.39 & 46.38 & 29.85 & $<0.001^{6}$ \\
\hline Fatigue & 72.92 & 23.66 & 55.59 & 16.91 & 48.48 & 17.54 & 35.72 & 21.33 & $<0.001^{7}$ \\
\hline Eating activities & 56.67 & 15.28 & 35.00 & 29.06 & 20.82 & 18.85 & 7.57 & 9.23 & $<0.001^{8}$ \\
\hline Speech & 92.36 & 8.42 & 25.99 & 33.61 & 25.16 & 30.05 & 8.27 & 15.87 & $<0.001^{9}$ \\
\hline Daily activities & 13.89 & 19.45 & 10.23 & 15.90 & 3.03 & 6.99 & 1.00 & 3.82 & $<0.001^{10}$ \\
\hline School activities & 37.50 & 28.64 & 16.12 & 22.47 & 5.99 & 11.40 & 1.23 & 4.31 & $<0.001^{11}$ \\
\hline $\begin{array}{l}\text { Movement } \\
\text { and balance }\end{array}$ & 45.00 & 17.32 & 58.68 & 29.19 & 29.45 & 23.49 & 15.07 & 19.15 & $<0.001^{12}$ \\
\hline
\end{tabular}

III vs. III, $p<0.001$; II vs. IV, $p<0.001$; II vs. V, $p<0.001$; III vs. V, $p=0.012$; IV vs. V, $p=0.047 ;{ }^{2} / I$ vs. V, $p=0.002 ;$ III vs. V, $p=0.031 ;{ }^{3} / \mathrm{V}$

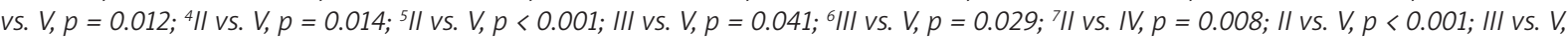
$p=0.034 ; 8 / I$ vs. III, $p=0.005$; II vs. IV, $p<0.001$; II vs. V, $p<0.001$; III vs. V, $p<0.001 ; 9$ II vs. III, $p=0.005 ;$ II vs. IV, $p<0.001 ;$ II vs. V, $p<0.001$; ${ }^{10} / I$ vs. IV, $p=0.003$; II vs. V, $p<0.001$; III vs. IV, $p=0.045$; III vs. V, $p=0.014 ;{ }^{11} I I$ vs. III, $p<0.001 ;$ II vs. IV, $p<0.001 ;$ II vs. V, $p<0.001 ; I I I$ vs. $V, p=0.005 ;{ }^{12} / I$ vs. $V, p=0.005 ;$ III vs. IV, $p=0.006 ;$ III vs. V, $p<0.001$

disorders in persons with TCP may result in secondary musculoskeletal problems and health problems increasing with age, including chronic pain. Among population-based studies of $\mathrm{CP}$, males have been found to have higher prevalence of $\mathrm{CP}$ than females. It was suspected that gender may influence the motor outcome and cognitive development in children with CP. In our study, similarly as in others [32, 43, $44,46]$, no impact of demographic factors on HRQOL was noticed. The results indicate that gender and age may be less important factors of well-being. More detailed longitudinal studies are required, especially in the case of adults. According to Usuba et al. [47], deteriorations in the HRQOL were most evident in adults with CP in their late 20s and 30s.

In the CP Module the top-rated feature was pain and hurt. In the study group a statistically significant difference in the subscale between a group of 2-4-year-olds and a group of over-8-year-olds was revealed, which indicates an increase in discomfort connected with pain. Significant differences were also noticed at the II and IV and II and V level of GMFCS. Children with TCP self-reported greater pain severity than children with hemiplegia or diplegia [27]. The same pattern was found for parent proxy-reports of children's pain [27, 42].

Our studied showed that higher gross motor functioning (lower GMFCS level) and higher fine motor functioning (lower MACS level) were associated with higher PedsQL CP Module scores. These results are concordant with other papers concerning the GMFCS system [29, 32, 36, 42, 43, 48] and MACS system [42, 48]. The level of MACS correlated with all elements of Generic Core of the PedsQL 4.0 and CP Module. For contrast, social functioning was not associated with level of GMFCS and degree of intellectual disability. The lack of correlation between the GMFCS level and psychosocial HRQOL has been noticed before [32, 43, 46, 49].

The present study has its strengths and limitations. The major strength is the size of the sample included in the survey. To our knowledge, this is the first study in Poland on a large population of children 
with TCP, who were recruited from southern and central Poland. The major limitation is basing the study on parent-proxy reporting. It is, however, the only possibility of assessing HRQOL in severe cases of CP.

\section{Conclusions}

Cerebral palsy is the most common motor disability during childhood, and it is associated with other conditions. The severity of symptoms varies between individuals, and the same may be said about healthrelated quality of life. Increasing life expectancy of persons with severe $\mathrm{CP}$ may result in a decline in their medical and functional status. In such a case the HRQOL evaluation is of special importance because it may be useful for identifying and prioritising health problems. This study showed significant deficits in HRQOL for children with TCP, especially as regards physical HRQOL. Future studies will be needed to search for variables that could influence psychosocial HRQOL. In the case of children with limited cognitive or communication abilities, special attention should be paid to possibilities and ways of assessing emotional state, as well as pain and fatigue, i.e. domains particularly relevant to aging.

\section{Conflict of interest}

The authors declare no conflict of interest.

\section{References}

1. Rosenbaum P, Paneth N, Leviton A, Goldstein M, Bax M Damiano D, Dan B, Jacobsson B. A report: the definition and classification of cerebral palsy April 2006. Dev Med Child Neurol Suppl 2007; 109: 8-14.

2. Pakula AT, Van Naarden Braun K, Yeargin-Allsopp M. Cerebral palsy: classification and epidemiology. Phys Med Rehabil Clin N Am 2009; 20: 425-452.

3. Venkateswaran S, Shevell MI. Comorbidities and clinical determinants of outcome in children with spastic quadriplegic cerebral palsy. Dev Med Child Neurol 2008; 50 216-222.

4. Andersen GL, Irgens LM, Haagaas I, Skranes JS, Meberg AE, Vik T. Cerebral palsy in Norway: prevalence, subtypes and severity. Eur J Paediatr Neurol 2008; 12: 4-13.

5. Odding E, Roebroeck ME, Stam HJ. The epidemiology of cerebral palsy: incidence, impairments and risk factors. Disabil Rehabil 2006; 28: 183-191.

6. Surveillance of cerebral palsy in Europe (SCPE): Prevalence and characteristics of children with cerebral palsy in Europe. Dev Med Child Neurol 2002; 44: 633-640.

7. Westbom L, Hagglund G, Nordmark E. Cerebral palsy in a total population of 4-11 year olds in southern Sweden. Prevalence and distribution according to different CP classification systems. BMC Pediatr 2007; 7: 41.

8. Zgorzalewicz B, Mieszczanek T, Zgorzalewicz M. Epidemiologia opisowa mózgowego porażenia dziecięcego, Ortop Traum Rehab 2001; 3: 467-471.

9. Bax M, Tydeman C, Flodmark O. Clinical and MRI correlates of cerebral palsy: the European cerebral palsy study. JAMA 2006; 296: 1602-1608.
10. Shevell MI, Dagenais L, Hall N. The relationship of cerebral palsy subtype and functional motor impairment: a population-based study. Dev Med Child Neurol 2009; 51: 872-877.

11. Kulak W, Sobaniec W, Smigielska-Kuzia J, Kubas B, Walecki J. A comparison of spastic diplegic and tetraplegic cerebral palsy. Pediatr Neurol 2005; 32: 311-317.

12. Edebol-Tysk K, Hagberg B, Hagberg G. Epidemiology of spastic tetraplegic cerebral palsy in Sweden. II. Prevalence, birth data and origin. Neuropediatrics 1989; 20: 46-52.

13. Himmelmann K, Beckung E, Hagberg G, Uvebrant P. Gross and fine motor function and accompanying impairments in cerebral palsy. Dev Med Child Neurol 2006; 48: 417-423.

14. WHO. The World Health Organization quality of life assessment (WHOQOL): position paper from the World Health Organization. Soc Sci Med 1995; 41: 1403-1409.

15. Majnemer A, Shevell M, Law M, Poulin C, Rosenbaum P. Reliability in the ratings of quality of life between parents and their children of school age with cerebral palsy. Qual Life Res 2008; 17: 1163-1171.

16. White-Koning M, Arnaud C, Dickinson HO, Thyen U, Beckung E, Fauconnier J, McManus V, Michelsen SI, Parkes J, Parkinson K, Schirripa G, Colver A. Determinants of child-parent agreement in quality-of-life reports: a European study of children with cerebral palsy. Pediatrics 2007; 120: 804-814.

17. White-Koning M, Grandjean H, Colver A, Arnaud C. Parent and professional reports of the quality of life of children with cerebral palsy and associated intellectual impairment. Dev Med Child Neurol 2008; 50: 618-624.

18. White-Koning $M$, Arnaud $C$, Bourdet-Loubère $S$, Bazex $H$, Colver A, Grandjean H. Subjective quality of life in children with intellectual impairment: how can it be assessed? Dev Med Child Neurol 2005; 47: 281-285.

19. Waters E, Doyle J, Wolfe R, Wright M, Wake M, Salmon L. Influence of parental gender and self-reported health and illness on parent-reported child health. Pediatrics 2000; 106: $1422-1428$

20. Arnaud C, White-Koning M, Michelsen SI, Parkes J, Parkinson K, Thyen U, Beckung E, Dickinson HO, Fauconnier J, Marcelli M, McManus V, Colver A. Parent-reported quality of life of children with cerebral palsy in Europe. Pediatrics 2008; 121: 54-64.

21. Cremeens J, Eiser C, Blades M. Factors influencing agreement between child self-report and parent proxy-reports on the Pediatric Quality of Life Inventory 4.0 (PedsQL) generic core scales. Health Qual Life Outcomes 2006; 4: 58.

22. Kochman D. Jakość życia. Analiza teoretyczna. Zdr Publ 2007; 117: 242-248.

23. Varni JW, Seid M, Rode CA. The PedsQL: measurement model for the Pediatric Quality of Life Inventory. Med Care 1999; 37: 126-139.

24. Varni JW, Limbers CA, Burwinkle TM. Parent proxy-report of their children's health-related quality of life: an analysis of 13,878 parents' reliability and validity across age subgroups using the PedsQL 4.0 Generic Core Scales. Health Qual Life Outcomes 2007; 5: 2.

25. Varni JW, Burwinkle TM, Seid M, Skarr D. The PedsOL 4.0 as a pediatric population health measure: feasibility, reliability, and validity. Ambul Pediat 2003; 3: 329-341.

26. Varni JW, Limbers CA. The PedsQL 4.0 Generic Core Scales Young Adult Version: feasibility, reliability and validi- 
ty in a university student population. J Health Psychol 2009; 14: 611-622.

27. Varni JW, Burwinkle TM, Berrin SJ, Sherman SA, Artavia K, Malcarne VL, Chambers HG. The PedsQL in pediatric cerebral palsy: reliability, validity, and sensitivity of the generic core scales and cerebral palsy module. Dev Med Child Neurol 2006; 48: 442-449.

28. Varni JW, Burwinkle TM, Sherman SA, Hanna K, Berrin SJ, Malcarne VL, Chambers HG. Health-related quality of life of children and adolescents with cerebral palsy: hearing the voices of children. Dev Med Child Neurol 2005; 47: 592-597.

29. Pirpiris M, Gates PE, McCarthy JJ, D’Astous J, Tylkowski C, Sanders JO, Dorey FJ, Ostendorff S, Robles G, Caron C, Otsuka NY. Function and well-being in ambulatory children with cerebral palsy. J Pediatr Orthop 2006; 26: $119-124$

30. Du RY, McGrath C, Yiu CK, King NM. Health- and oral health-related quality of life among preschool children with cerebral palsy. Qual Life Res 2010; 19: 1367-1371.

31. Livingston MH, Rosenbaum PL, Russell DJ, Palisano RJ. Quality of life among adolescents with cerebral palsy: what does the literature tell us? Dev Med Child Neurol 2007; 49: 225-231.

32. Vargus-Adams J. Health-related quality of life in childhood cerebral palsy. Arch Phys Med Rehabil 2005; 86: 940-945.

33. Sandella DE, O'Brien LM, Shank LK, Warschausky SA. Sleep and quality of life in children with cerebral palsy. Sleep Med 2011; 12: 252-256.

34. Russo RN, Goodwin EJ, Miller MD, Haan EA, Connell TM, Crotty M. Self-esteem, self-concept, and quality of life in children with hemiplegic cerebral palsy. J Pediatr 2008; 153: 473-477.

35. Bjornson KF, Belza B, Kartin D, Logsdon RG, McLaughlin J. Self-reported health status and quality of life in youth with cerebral palsy and typically developing youth. Arch Phys Med Rehabil 2008; 89: 121-127.

36. Janssen CG, Voorman JM, Becher JG, Dallmeijer AJ, Schuengel C. Course of health-related quality of life in 9-16-year-old children with cerebral palsy: associations with gross motor abilities and mental health. Disabil Rehabil 2010; 32: 344-351.

37. Soyupek F, Aktepe E, Savas S, Askin A. Do the self-concept and quality of life decrease in CP patients? Focussing on the predictors of self-concept and quality of life. Disabil Rehabil 2010; 32: 1109-1115.

38. Dickinson HO, Parkinson KN, Ravens-Sieberer U, Schirripa $\mathrm{G}$, Thyen U, Arnaud C, Beckung E, Fauconnier J, McManus V, Michelsen SI, Parkes J, Colver AF. Self-reported quality of life of 8-12-year-old children with cerebral palsy: a cross-sectional European study. Lancet 2007; 369: 2171-2178.

39. Varni JW, Limbers CA, Burwinkle TM. Impaired healthrelated quality of life in children and adolescents with chronic conditions: a comparative analysis of 10 disease clusters and 33 disease categories/severities utilizing the PedsQL 4.0 Generic Core Scales. Health Qual Life Outcomes 2007; 5: 43.

40. Okurowska-Zawada B, Kułak W, Otapowicz D, Sienkiewicz D, Paszko-Patej G, Wojtkowski J. Quality of life in children and adolescents with cerebral palsy and myelomeningocele. Pediatr Neurol 2011; 45: 163-168.
41. Karaduman A, Yilmaz Ö, Tüzün EH, Kerem Günel M, Aras B, Mutlu A, Tarsuslu T, Aras Ö. A comparison of quality of life in children with cerebral palsy and neuromuscular diseases. Fizyoterapi Rehabilitasyon 2010; 21: 3-10.

42. Michalska A, Wendorff J, Boksa E, Wiktor PJ. Jakość życia dzieci i młodzieży z mózgowym porażeniem dziecięcym i niepełnosprawnością intelektualną. Wybrane uwarunkowania kliniczne. Neurol Dziec 2012; 21: 39-48.

43. Maher CA, Olds T, Williams MT, Lane AE. Self-reported quality of life in adolescents with cerebral palsy. Phys Occup Ther Pediatr 2008; 28: 41-57.

44. Michalska A, Boksa E, Wendorff J, Wiktor PJ. Jakość życia dzieci i młodzieży z mózgowym porażeniem dziecięcym i niepełnosprawnością intelektualną. Wybrane uwarunkowania społeczno-demograficzne. Neurol Dziec 2012; 21: $35-44$.

45. Radsel A, Osredkar D, Neubauer D. Health-related quality of life in children and adolescents with cerebral palsy. Zdr Varst 2016; 56: 1-10.

46. Tessier DW, Hefner JL, Newmeyer A. Factors related to psychosocial quality of life for children with cerebral palsy. Int J Pediatr 2014; 2014: 204386.

47. Usuba K, Oddson B, Gauthier A, Young NL. Changes in gross motor function and health-related quality of life in adults with cerebral palsy: an 8-year follow-up study. Arch Phys Med Rehabil 2014; 95: 2071-2077.

48. Park EY. Relationship between activity limitation and health-related quality of life in school-aged children with cerebral palsy: a cross-sectional study. Health Qual Life Outcomes 2017; 15: 87.

49. Majnemer A, Shevell M, Rosenbaum P, Law M, Poulin C. Determinants of life quality in school-age children with cerebral palsy. J Pediatr 2007; 151: 470-5.

\section{Address for correspondence:}

\section{Agata Michalska}

Department of Neurology, Neurologic Rehabilitation and Kinezytherapy

Institute of Physiotherapy

Faculty of Health Sciences

Jan Kochanowski University

Kielce, Poland

Phone: +48 698463899

E-mail: michalskaagata.reh@gmail.com 